\title{
ANALISIS TOKOH KEARSIPAN \\ (BARBARA L. CRAIG DAN LUCIANA DURANTI)
}

\author{
Yogi Andrianza \\ Pascasarjana UIN Sunan Kalijaga, Yogyakarta \\ Khairunisa \\ Pascasarjana UIN Sunan Kalijaga, Yogyakarta \\ Dio Eka Prayitno \\ Pascasarjana UIN Sunan Kalijaga, Yogyakarta \\ Email: yandrianza@gmail.com
}

\begin{abstract}
Abstrak
Artikel ini bertujuan untuk memberikan gambaran mengenai tokoh kearsipan berkebangsaan Kanada yaitu Barbara L. Craig dan Luciana Duranti. Metode penelitian dalam penulisan artikel ini menggunakan Studi Pustaka dengan metode pengumpulan data melalui artikel dari jurnal maupun artikel yang berkaitan dengan tema penulisan kemudian di analisis oleh penulis. Artikel ini membahas mengenai biografi, karya dan kontribusi tokoh dari dunia kearsipan. Hasil dari artikel ini menyebutkan yaitu bahwa Barbara L. Craig merupakan tokoh arsiparis yang selalu berperan aktif pada kegiatan kearsipan dan medapatkan beberapa penghargaan dari oragnisasi kearsipan, sedangkan Luciana Duranti merupakan tokoh yang berperan penting dalam bidang kearsipan juga memberikan kontribusi mengenai salah satu diantaranya yaitu ikatan arsip.
\end{abstract}

KATA KUNCI: Arsiparis, Tokoh Arsip, Kearsipan, Barbara L. Craig, Luciana Duranti.

\begin{abstract}
This article aims to provide an overview of Canadian archival figures, namely Barbara L. Craig and Luciana Duranti. The research method in writing this article uses a Literature Study with data collection methods through articles from journals and articles related to the theme of writing and then analyzed by the author. This article discusses biographies, works and contributions of figures from the world of archives. The results of this article state that Barbara L. Craig is an archivist who always plays an active role in archival activities and has received several awards from archival organizations, while Luciana Duranti is a figure who plays an important role in the field of archiving and also contributes to one of them, namely archives.
\end{abstract}

KATA KUNCI:Arsiparis, Tokoh Arsip, Kearsipan, Barbara L. Craig, Luciana Duranti. 


\section{PENDAHULUAN}

Di era yang semakin berkembang seperti saat ini, tentu perlu diketahui bahwa beberapa profesi sangat berperan penting terhadap kontribusi baik pada negaranya maupun kepada lingkungannya. Seperti halnya pada lembaga atau organisasi yang berperan dalam memberikan layanan informasi seperti perpustakaan, lembaga kearsipan maupun lembaga informasi lainnya yang sejenis, maka lembaga atau organisasi tersebut sangat berperan dalam memenuhi kebutuhan informasi kepada masyarakat. Tujuan utamanya yaitu memberikan kemudahan dalam mengakses informasi yang masyarakat butuhkan dengan berbagai macam tujuan seperti pendidikan, penelitian maupun aktifitas lain.

Peran penting yang dilakukan oleh para profesional terkadang menjadi hal yang terlupakan ketika pengguna informasi tidak memanfaatkan para professional tersebut. Professional di sini adalah profesi arsiparis yang menjadi fokus penulis. Namun pada kenyataannya pengguna informasi lebih suka mencari informasi secara mandiri. Hal ini disebabkan oleh ketidaktahuan atau kurangnya pemahaman pengguna informasi dalam memanfaatkan jasa layanan informasi di lembaga kearsipan, sehingga perlu sekali tokoh arsiparis selaku profesi yang memberikan layanan informasi memberikan kontribusi baik kepada penguna infomasi, lembaga informasi dan kearsipan.

Dalam tulisan ini penulis ingin menguraikan lebih jauh mengenai Analisis terhadap tokoh arsiparis berkebangsaan Kanada yaitu Barbara L. Craig dan Luciana Duranti yang memberikan kontribusi dalam dunia kearsipan.

\section{METODE}

Metode penulisan pada artikel ini menggunakan Studi Pustaka. Metode pengumpulan data yakni dengan mengumpulkan beberapa jurnal dan artikel yang berkaitan dengan tokoh tersebut kemudian penulis melakukan analisis terhadap tokoh tersebut 


\section{HASIL DAN PEMBAHASAN}

\section{A. Barbara Lazenby Craig}

Barbara Lazenby Craig lahir di Toronto, Kanada pada tahun 1943. Ia adalah seorang profesor arsip dan Direktur pusat penelitian dalam studi informasi, Fakultas Studi Informasi Universitas Toronto. Craig merupakan seorang arsiparis Universitas York. Pada tahun 1989 ia menjabat sebagai kepala departemen arsip dan koleksi khusus di perpustakaan Scott (Scott Library) dan seorang arsiparis di arsip Ontario sejak tahun 1970. Ia memiliki gelar Ph.D. dalam bidang arsip dan telah melakukan penelitian ekstensif di rumah sakit Kanada, Amerika Serikat dan Inggris. Ia menerbitkan tentang sejarah pencatatan, sejarah kedokteran, arsip medis, dan teori arsip (B. L. Craig, 2000). Barbara Craig memulai karirnya dalam bidang arsip pada tahun 1970 sampai 1988 di arsip Ontario. Sejak tahun 1976, Profesor Craig telah melayani banyak organisasi profesional termasuk Dewan Arsip Ontario, yang dipimpinnya sejak 1989 - 1993, Asosiasi Pengarsip Kanada dan pernah menjabat sebagai presiden pada tahun 1983 hingga 1984, Dewan Arsip Kanada dan kelompok nasional dan internasional lainnya, dan telah melayani di banyak komite sebagai anggota dan ketua (Association of Canadian Archivists, 2016). Selain itu Craig adalah salah sorang dari editorial board pada Journal Archivaria dari tahun 2000 sampai 2006, kemudian juga menjabat sebagai Editor Umum serving as General Editor dari tahun 2002 sampai 2004.

Sebagai seorang Sarjana, Craig telah menghasilkan karya yang berupa buku sebanyak 6 judul, artikel sebanyak 44 judul yang terbuat di berbagai macam jurnal seperti Archivaria, Archival Science, American Archivist, the Canadian Bulletin of Medical History. Selain itu, dia telah mempresentasikan ide-idenya secara internasional, mengirimkan 60 makalah dan seminar ke konferensi dan pertemuan. Karya ilmiahnya, khususnya pada arsip medis dan penilaian arsip, sangat memperkaya pemahaman kita tentang teori dan praktik kearsipan (Association of 
Canadian Archivists, 2016). Adapun karya karyanya meliputi 6 buku, dan 24 artikel.

Selain karya karya yang dihasilkan tersebut, Barbara L. Craig juga memperoleh penghargaan dibidang kearsipan diantaranya yaitu pada tahun 1991 yang didapatkan dari Asosiasi Arsiparis Kanada mengenai pengembangan teori arsip, kemudian pada tahun 2008 memperoleh penghargaan yang sama dari Asosiasi Arsiparis Kanada yaitu membership awards. Lalu pada tahun 2009 Barbara L. Craig menjadi anggota pendiri Asosiasi Arsiparis Kanada lalu pada tahun 2010 diberikan penghargaan oleh James T Jalman dari Asosiasi Arsip Ontario.

Kontribusi Barbara Craig dalam dunia arsip yaitu sebuah teori terhadap penilaian arsip yang disampaikan melalui bukunya yang berjudul Archival Appraisal: Theory and Practice tahun 2004 yaitu Systematic and planned approaches that are strategically conceptualized have four key features.

Selain menjadi arsiparis yang sukses dalam karir Barabara L. Craig juga menulis tentang teori dan praktek arsip dalam sebuah tulisannya yang menggambarkan bahwa Penilaian koleksi merupakan bagian integral dari pekerjaan arsip dan sumber referensi profesional yang unik ini memberikan informasi rinci tentang teknik dan rekomendasi terbaru dalam menghadapi banjir informasi yang sekarang dihadapi spesialis informasi, manajer arsip, manajer pengetahuan, dan arsiparis. Penilaian Arsip memberikan contoh: proses perencanaan akuisisi; kebijakan akuisisi; prosedur akuisisi; kriteria penilaian dan formulir laporan penilaian. Ini adalah pengantar yang sangat baik untuk subjek dengan tata letak yang jelas dan ramah pembaca, memberikan penjelasan teori yang baik dan menjelaskan praktik penilaian arsip. Ada juga daftar istilah dengan penjelasan rinci tentang artinya. Karya ini merupakan karya referensi penting bagi siapa saja yang memiliki tanggung jawab atas arsip serta pengelolaan dan penggunaannya (B. Craig, 2005).

\section{B. Luciana Duranti}


Luciana Duranti lahir pada 28 September 1950. Ia merupakan seorang ahli arsip, profesor ilmu kearsipan dan diplomatik di School of Library Archival and Information Studies Universitas British Columbia di Vancouver, Kanada. Ia menjabat sebagai Direktur penelitian catatan elektronik interPARES (Penelitian Internasional tentang Catatan Outentik Permanen dalam Sistem Elektronik) sejak tahun 1998 sebuah proyek penelitian multi-nasional dan multi-disiplin yang mempelajari pelestarian arsip elektronik autentik jangka panjang. Dia juga Ketua Komite Dewan Standar Pemerintah Kanada untuk standar "Catatan Elektronik sebagai Bukti Dokumenter. Pada tahun 2017 Luciana Duranti terpilih sebagai Presiden Association of Canadian Archivists (ACA) dengan masa jabatan 1 tahun terhitung sejak 1 Januari 2017 sampai 31 Desember 2018.

Duranti Merupakan orang pertama yang menjabat sebagai Presiden Society of American Archivist (SAA) dan ACA. Dia juga merupakan Fellow SAA (1998) dan ACA (2014). Ia mulai menggeluti bidang kearsipan pada tahun 1973, dan menjadi guru besar dalam bidang kearsipan di sekolah sejak 1987. Selain mengajar, ia melakukan berbagai kegiatan ilmiah, profesional, dan diseminasi pengetahuan, termasuk partisipasi dalam kegiatan nasional, konferensi, komite, dan organisasi internasional, seperti UNESCO; penyampaian ceramah umum dalam acara-acara terbuka untuk audiens non-spesialis dan ceramah undangan di beberapa universitas, dan publikasi di bidang ilmu kearsipan dan sejarah dan diplomatik. Yang paling penting adalah karyanya dengan komite pendidikan ACA, yang melibatkan penulisan "Pedoman Pengembangan Kurikulum Dua Tahun untuk Program Magister Studi Kearsipan" (UBC School of Information, n.d.).

Beberapa karya duranti bidang diplomatika kearsipan dan teori kearsipan di presentasikan dalam konferensi dan symposium di seluruh dunia diantaranya yaitu 1) Diplomatics: New Uses for an Old Science tahun 1998 dengan ISBN 978-0810835283 dan Encyclopedia of archival tahun 2015 dengan ISBN 978-0-8108-8810-4. Selain itu Duranti juga memperoleh penghargaan Rekan, Asosiasi Arsiparis Kanada pada tahun 2014, Penghargaan dari Emmeth Leahy pada tahun 2006 dan Rekan, Society of 
American Archivist pada tahun 1998. Selain itu Luciana Duranti juga merupakan pencetus konsep ikatan arsip dimana menurutnya ikatan arsip tidak harus disamakan dengan istilah "konteks" yang lebih luas karena konteks ada terlepas dari catatan sementara dan ikatan arsip merupakan bagian penting dari sebuah catatan yang tidak aka nada tanpanya (Duranti, 1997)

\section{PENUTUP}

\section{Simpulan}

Dari paparan diatas dapat ditarik kesimpulan bahwa masing-masing tokoh memiliki peran penting dalam dunia kearsipan. Dalam kontribusinya Barbara L. Craig menuangkan teorinya dalam sebuah tulisan tentang penilaian arsip yang disampaikan melalui bukunya yang berjudul Archival Appraisal: Theory and Practice tahun 2004. Atas karya-karyanya barbara beberapa kali mendapatkan penghargaan di bidang kearsipan. Sedangkan Luciana Duranti juga merupakam tokoh arsiparis yang memiliki banyak prestasi dan karir dalam bidang kearsipan, Luciana Duranti juga merupakan pencetus konsep ikatan arsip dalam karyanya yang berjudul the archival Bond. Kedua tokoh arsiparis ini merupakan tokoh yang benarbenar mendalami keilmuan dalam bidang arsip sehingga mereka mampu memberikan kontribusi terhadap asosiasi dan lembaga kearsipan atau sejenisnya. 


\section{DAFTAR PUSTAKA}

Association of Canadian Archivists. (2016, May 6). ACA Award Recipient Biographies.

https:/ /web.archive.org/web/20160506230755/http://archivists.ca/ content/aca-award-recipient-biographies

Craig, B. (2004). Archival Appraisal: Theory and Practice. K. G. Saur Verlag $\mathrm{GmbH}$.

Craig, B. L. (2000). Canadian Archivists: What Types of People Are They? Archivaria, 79-92.

Duranti, L. (1997). The Archival Bond. Archives and Museum Informatics, 11(3), 213-218. https:/ / doi.org/10.1023/A:1009025127463

UBC School of Information. (n.d.). Retrieved June 3, 2021, from https: / ischool.ubc.ca/2016/06/dr-luciana-duranti-elected-next-acapresident/ 